\title{
The Role of Competitiveness as Mediator for the Relation between Supply Chain Flexibility and Firm Performance
}

\author{
La Hatani (Corresponding author) \\ Department of Management Faculty of Economics \\ Haluoleo University, Kendari, Southeast Sulawesi, Indonesia \\ E-mail: hatani1974@gmail.com
}

Djumilah Zain

Professor, Department of Management, Faculty of Economics and Business

Brawijaya University, Malang, East Java, Indonesia

\author{
Budisantoso Wirjodirjo \\ Professor, Department Of Industrial Engineering \\ Institute Of Technology “Sepuluh November”, Surabaya, East Java, Indonesia
}

Djumahir

Department of Management, Faculty of Economics and Business

Brawijaya University, Malang, East Java, Indonesia

Received: Dec. 18, 2012 Accepted: January 7, 2012 Published: January 8, 2013

doi:10.5296/jmr.v5i1.2904 URL: http://dx.doi.org/10.5296/jmr.v5i1.2904

\begin{abstract}
The purpose of this paper is to explore the impact of supply chain flexibility on the competitiveness and firm performance and to explain the role of competitiveness as mediator for the relation between supply chain flexibility and firm performance. Methods of data
\end{abstract}




\section{Macrothink}

collection was survey. The sample was the manager of large-scale fishery firms in the Southeast Sulawesi. Research results showed the high supply chain flexibility has a significant effect on higher competitiveness, but does not has significant effect on firm performance, there for competitiveness has significant effect on firm performance. Finally, competitiveness becomes a complete mediation relationship between supply chain flexibility on firm performance. The practical implications of this study was to provide insight and knowledge to fishery firm managers, particularly in Southeast Sulawesi and Indonesia and generally in other developing countries, in implementing the concept supply chain flexibility by observing the capability of their partners in the supply chain to respond market changes in achieving and maintaining competitiveness and firm performance. Originality of this research was to provide the basis for an integrated configuration model in testing the relationship between supply chain flexibility on competitiveness and firm performance, and also on the role of competitiveness as mediator in improving firm performance.

Keywords: Supply Chain Flexibility, Competitiveness, Performance 


\section{Introduction}

In the era of modern business highly competitive, manufacturing climate is characterized by increasingly sophisticated consumers that demand customized products and short lead times. Many companies that have previously relied on order winning through low cost standardized production have had to become more flexible in order to compete. Authors have acknowledged the importance of flexibility in meeting customer demands and improving responsiveness. The competitors' composition of resource can be obtained in many parts of the world, so that supply chain flexibility (SCF) should receive a special focus from manufacturing companies in fishery sector so that they can improve their competitiveness and firm performance. The effort to support industrialization in fishery sector as outstanding commodity of a region should be given a priority to the improvement of competitiveness and added-value, which is affected among others by improving supply chain and value chain management. So far, the distribution of fish from production centers to various regions is not optimal, while the stability of fish supply is necessary for the consumption and processing industry. Therefore, the central government has planned to develop a national fish logistics system to facilitate the distribution of fish from regions and to serve as the initial step in improving the fish supply chains.

The synergy between the central government, regional government, the private business and wide public is the key to the success for the effort to improve product competitiveness and performance of fishery companies. The development of fishery company performance in Southeast Sulawesi up to 2011 is only $73.88 \%$, equivalent to a decrease of $10.20 \%$ compared to 2010. The factors influencing this decrease in fishery companies performance are: (1) less than conducive competition among fishery companies; (2) rationalization of business sector which result in the reduction of production and kinds of processed fish; (3) inability to continue operation for two companies due to financial problems; (4) four state-owned fishery companies are merged due to worsening liquidity (CSA, 2011).

This would be determined by the firm capability in building effective relations in an integrated manner among its business partners. A company's success is determined not only by the company's own performance but also by the performance of the whole network (Haizer \& Render, 2010). With the proliferation of product varieties and the increased volatility of the global marketplace, uncertainty is now an important feature of the contemporary business environment. Flexibility represents the capability of a firm to respond to unanticipated environmental changes in its production process and in the marketplace. Manufacturing flexibility, which is one of the major competitive weapons for manufacturers in today's increasingly turbulent market (Candace et al., 2011), has been well acknowledged and studied in previous research.

Intense competition among companies, along with increasing demand from consumers who would want products which are not only more affordable but also have higher quality, innovative and matched with their demand, and delivered on-time, has made it important to implement SCF, especially for the fishery firm in Southeast Sulawesi. Environmental uncertainty, inter-organizational relation and information sharing are the factors for 
consideration in SCF (Mark Stevenson \& Martin Spring, 2007). The result of previous research has shown that SCF can improve competitiveness (Vinod Kumar et al., 2007; Pujawan, 2004) and has significant impact on company performance (Angel \& Manuela, 2005). The result of several theoretical studies (Candace et al., 2011; Quah Hock \& Zulfikli, 2011) show that a company facing highly dynamic environment must be agile and improve its flexibility if it wants to survive intense competition. The supply chain capability must be flexible in terms of operation, supply and supply chain network. Flexibility would be beneficial for the supply chain and for responsive customer. This is different from the findings of Kamel A.Fantazy et al., (2009) that SCF does not have significant impact on company performance and it also recommends the need to carry out empirical studies to test the nature and sharing of responsibility among partners in a supply chain.

Previous studies have shown that high competitiveness can directly improve performance (Suhong Li et al., 2006; Gimenez \& Ventura, 2003;2005; Soo W. Kim, 2006a; Rajesh \& Margaret, 2009; Glenn Richey et al., 2009). However there are still mixed findings on the impact of competitiveness on company performance (Ting Chi et al., 2009; Soo W. Kim, 2006b), since some studies shows that competitiveness do not have significant impact on performance for small companies and has significant impact only for big companies. SCF can increase competitiveness and firm performance. However, debate continues both theoretically and empirically. The situation needs to be clarified through empirical studies, as we did this study. In addition, this study seeks to investigate the competitive advantage role as mediating the relationship of SCF on firm performance. Thus, further research needs to be done, particularly the fishery firms in Southeast Sulawesi. The motivation for this research is as follows: the first, this research attempts to build a model for the integrated relation between SCF and competitiveness and firm performance, which has been studied previously in separate studies. This research is expected to find the role of competitiveness as mediator for the improvement of company performance as mediated by SCF. The second, is that the test for the relation between SCF and company competitiveness and performance is still plagued by contradictions, which is caused by basic differences in the basic theories and variety in the measurement indicators. Lack of consistency and lack of concept clarity for the indicators of SCF have shown that there is an urgent need to re-examine the matter.

The last is that previous studies focused on the impact performance SCF on competitiveness and performance are still inconclusive and requires evidence for the generalization to manufacturing companies, especially fishery firm. SCF can create value added in order to enhance competitiveness and firm performance. Nevertheless, there was theoretical and empirical debate. In addition, the empirical support on fisheries sector, commodity from Southeast Sulawesi, which has made integrated implementation processes in the fisheries resources management, began to appear from supplier to the customer. However, its implementation was not flexible, especially to supplier. This condition was evidenced by potential support of ocean waters that can be used sustainable in Southeast Sulawesi province. The estimation were 250,000 tons per year. Utilization rate by year 2010 was 221,412 tons, worth 2.34 trillion rupiah. This potential utilization has great contributed to national and regional development. Ironically, fish processing firms in Southeast Sulawesi province in 
2010 only reached production level of 22801.40 tons. When compared to the year 2009, 23011.70 tons, there was a decrease (CSA, 2011).

The fish processing production decline in Southeast Sulawesi province was caused by management crisis in some fishery firms, so reduced the activity. It was indication of firm inability to create SCF and build an integrated long-term relationship, especially with suppliers (fish collector) and customers. Competition between fish processing firm was happened primarily because fish processing firms from outside Southeast Sulawesi areas offer higher price to buy fish from the suppliers (fishermen). Based on the problems faced by the fishery firm in Southeast Sulawesi, theoretical debates and empirical gaps from previous research has attracted researchers attention to conduct this study. Key issues of this study was whether the implementation of SCF can make an impact on company competitiveness and performance both directly and through the mediation of competitiveness. Specifically, the problem of this research are: (1) whether SCF significantly influence competitiveness and firm performance, and (2) whether competitiveness capable to act as mediating the relationship between SCF and firm performance.

The objective of this research is to test and explain the impact of SCF on competitiveness and firm performance. This research also attempts to test and explain the role of competitiveness as mediator for the relation between SCF and fishery firm performance. Theoretical contribution of this study was to enrich the operational management theory, especially SCF , competitiveness and firm performance. Practical contribution expected was able to guide the firm's management and business people in the fishing industry in the Southeast Sulawesi. Strategic development and framework can be done through implementation of SCF using supply flexibility; delivery, production, and product development flexibility, in an effort to improve competitiveness and firm performance.

\section{Literature Review, Hypotheses and Conceptual Model}

\subsection{Supply Chain Flexibility}

Theoretical studies which serve as the basis for the measurement and test for the relations among variables in this research are the theory of SCF. This concepts start from manufacturing flexibility, which is a very complex concept. Several theoretical studies have examined the basic nature of manufacturing flexibility in a multidimensional manner. Flexibility is the ability of companies to adapt to the process of production in fulfilling the demands of the customers (Angel \& Manuela, 2005). SCF is important for the industry nowadays since global competition has created greater uncertainty within the company environment. Quah Hock \& Zulfikli (2011) states that empirical studies should be carried out concerning SCF and therefore this research also explores further the concept of SCF.

There is a critique on the concept of SCF from (Mark Stevenson \& Martin Spring, 2007; Candace et al., 2011) that studies on SCF at present are more focused on how environmental uncertainty can influence SCF, while there are still other factors which play important role in $\mathrm{SCF}$, that is inter-organizational relationship, competitiveness and performance of the company. The present research is focused on SCF in relation to the competitiveness and 
performance. The concept of SCF itself was first proposed as an improvement to the concept of manufacturing flexibility which is focused merely to internal aspects of the company (Vinod Kumar et al., 2006). SCF should be approached in an integrated manner and oriented towards customers. Duclos et al. (2003) states that literature review on flexibility still have some weaknesses in discussing the cross-functional and cross-business nature of SCF.

In contrast to the manufacturing flexibility concept, SCF was not just involve one element, but also involves flexibility in the overall enterprise network, including manufacturing. Therefore, it needed the close cooperative relationship among all channels in the supply chain, both from internal and external firms such as suppliers, distributors, and customers. SCF was used to analyze overall system capacity to accommodate fluctuations of suppliers, factories and customers. The framework can be used internally by manufacturing firm, without directly involving suppliers and customers in assessment process. It was more important if the assessment can be done together with the members of supply chain channel. Based on these criticisms, this research create relationship model of integrated SCF, reflected in ability of supply chain partners to respond the changes in achieving or maintaining market competitiveness and firm performance.

SCF requires that integration begins from the suppliers until the customers and this integration must be flexible to all changes caused by customer demand which is getting more and more critical day by day (Duclos et al., 2003; Vinod Kumar et al., 2006). One of the components of SCF includes the dimension of flexibility which requires that all participants in a supply chain can fulfill customer demand. Pujawan (2004) has proposed a framework on the concept of SCF which is an adaptation between the concept of integrative Supply Chain Management (SCM) and manufacturing flexibility. This framework is expected to represent the concept of SCF from the upstream to the downstream. Pujawan (2005) also states that SCF should be considered as the primary determinant for company competitiveness and performance. The theory of SCF is the basis for measurement and test for the relation between SCF and company competitiveness and performance.

Previous studies have shown that SCF can indeed improve competitiveness (Kamel A. Fantazy et al., 2009; Pujawan, 2004) and has significant impact on company performance (Angel \& Manuela, 2005). This is different from the findings of (Kamel A. Fantazy et al., 2009) which found that SCF does not have significant impact on firm performance. SCF simply explained as a reaction arising as a result of uncertainty. SCF arises from manufacturing flexibility literature. The majority of empirical studies only limited on flexibility within firm. They rarely explore inter-organizational components from SCF perspective. Therefore, this study developed a conceptual framework of SCF by exploring inter-organizational components, especially the suppliers and customers, in order to support competitiveness and firm performance. The improvement of company competitiveness and performance requires the coordination of the supply chain by adding information flow and improving communication effort (Mark Stevenson \& Martin Spring, 2007). Quah Hock \& Zulfikli (2011) recommends a model which can help in assisting the organization to select supply chain based on the customers when it enters the market with global competition. Referring to the arguments from previous studies, the following hypotheses are proposed: 
H1. SCF will be positively associated with firm competitiveness

H2. SCF will be positively associated with firm performance

\subsection{Competitive Advantage and Firm Performance}

Competitive advantage or competitiveness is a theory which is based on the idea that company performance depends on its resources and capability which are unique for the company itself and inimitable (David et al., 2011). Competitiveness is the core for company performance in a competitive market. Competition is the core of a company success or failure. Competitiveness would determine the appropriateness of company activities which can support company performance when it is carried out well (Porter, 2008). Competitive strategy is the search for a competitive position which can be beneficial for the company. Competitive strategy aims to gain an advantageous position which can be defended from the competitive factors in the industry. Competitiveness can be achieved through many ways, one of which is through SCF (Pujawan, 2004).

The impact of competitiveness on firm performance has been studied based on theories (Haizer \& Render, 2010; Krajewski et al., 2010) which state that an integrated implementation of SCM provide a strategic opportunity for creating competitiveness and this would in turn support firm performance. Firm performance is an accumulation of all the work done by organizational units or the company (Soeryanto, 2010). This idea is also supported by the findings from (Suhong Li et al., 2006; Gimenez \& Ventura, 2005; Glenn Richey et al., 2009), all of which state that high level of competitiveness can improve firm performance. Instead, the findings of (Ting Chi et al., 2009) and Kim, 2006b) suggests there was no significant relationship between competitiveness priority to firm performance. Based on influence competitiveness on firm performance from previous research, there was still a contradiction caused by variability in measurement of firm performance and competitiveness. The concept of competitiveness measurement indicators still unclear, encouraging researcher to develop indicators of post services to suppliers as an indicator in measuring competitiveness. Based on the previous theoretical and empirical literature, the following hypothesis is proposed:

H3. Competitiveness will be positively associated with firm performance.

SCF is a concept which started from manufacturing flexibility, where it is expected to able to increase competitiveness and in turn can support company performance. The implementation of SCF with contingency perspective can be used as test and means of gaining insight on the impact of SCF on competitiveness and performance on the levels of different critical contingency variables. Contingency perspective requires that researcher choose a variable and then specify how the SCF interacts individually with the variables of contingency to impact competitiveness and performance (Pujawan, 2005). SCF is the ability of supply chain partners to respond to market changes in gaining and maintaining competitiveness and to adapt strategies to respond consumer demand quickly (Gary Hamel et al., 1998). Several theoretical studies have examined the basic nature of manufacturing flexibility in a 
multidimensional and complex manner, which makes it difficult to understand properly (Kamel A. Fantazy et al., 2009).

The findings of Kamel A. Fantazy et al. (2009) has shown that SCF does not have significant impact on company performance, and therefore this concept should be expanded through competitiveness on company performance. Pujawan (2004) states that SCF should be viewed as the primary determinant for the improvement of company performance through competitiveness. For the long term, SCF can be used for improving performance and it should have an impact on company profit or performance as a whole (Candace et al., 2011). Based on the arguments of previous studies, the following hypothesis is proposed:

H4. Competitiveness mediates the effect of SCF on firm performance.

Based on the theoretical review and results of previous studies, a summary of the conceptual model and research hypotheses is presented in Figure 1.

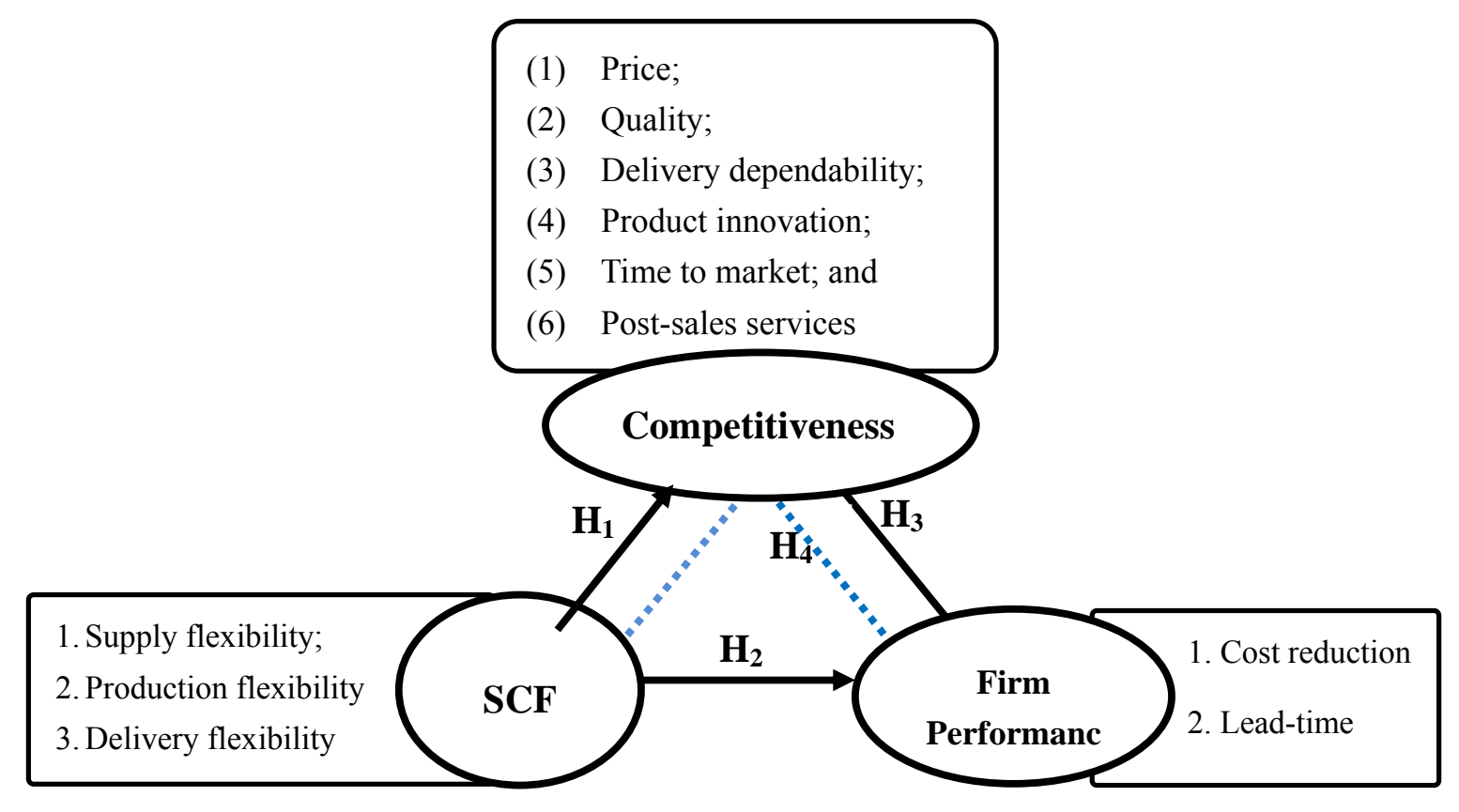

Notes: $\longrightarrow \quad$ Direct Effects; $\quad \cdots \cdots \cdots \quad$ Mediation Effects

Figure 1. Research Framework

\section{Methodology}

The design of this research uses explanatory research approach with the aim of making clear the relation between variables through hypothesis testing and making causal conclusion and then followed by choosing among alternatives of action. The reason for the use of explanatory research design is due to the objective of this research, that is to prove empirically and explain the impact of the implementation of integrative SCM and SCF on competitiveness and performance of fishery companies. The population for this research includes all large scale fishery companies operating in Southeast Sulawesi. The criteria for 
large scale manufacturing companies is taken from (CSA, 2011), that is the companies with more than 100 employees. The population of large scale fishery companies for this research is 44 companies. The distribution of companies in Southeast Sulawesi is 28 companies in the municipality of Kendari, 12 in the municipality of Bau-Bau, and 4 companies in the regency of Buton (CSA, 2011).

Sample was collected using a saturated sample method the population is relatively small and manageable by the researcher, that is 44 companies. The respondents are directors and managers of the companies. The number of respondent for each company is one person, that is the person from management level with titles such as director, CEO, operational manager, logistics manager, and quality control manager. Until the expiration of data collection period, the number of collected questionnaires is 42 or $95.45 \%$ of the total companies in the sample. Two companies cannot be access due to lack of permission from the management, without any reason being given. The directors or managers were chosen as respondent since they have the knowledge, ability and accuracy of response to the statements in the survey or questionnaire.

The data collection method used in this study was triangulation First, a literature review conducted to assess the theories or results of previous studies, which are relevant to the measures used in this study. SCF was responsiveness of integrated supply chain partner, particularly from suppliers, new product development, product processing and product delivery. Indicator measuring SCF was supply flexibility, production flexibility, delivery flexibility, and product development flexibility, adopted from (Pujawan, 2004; Candace et al., 2011; Quah Hock \& Zulkifli, 2011). Competitiveness was measured by firm ability to create a defensive position over its competitors. The indicator used was price; quality; delivery dependability; product innovation; time to market (Suhong Li et al., 2006; Soo W. Kim, 2006a; Ting Chi et al., 2009; David et al., 2011). This study develops a measurement with post service indicators to supplier. Construct firm performance was measured using absolute performance, firm ability to improve efficiency and effectiveness, adopted from (Gimenez \& Ventura, 2005; Suhong Li et al., 2006; Soo W. Kim, 2006b), including: cost; stock-out and lead-time reductions. Second, data collected using questionnaires, questions sent to managers at each fishery firm. Deployment was done by visiting firm and explain the questionnaire and waiting when the questionnaire can be taken from firm.

Finally, the data collection in this study was completed with in-depth interviews. This technique was used to support and to uncover the facts behind the findings of quantitative analysis. Data collection with in-depth interviews method refer to (Creswell, 2011). In-depth interviews using two ways, namely open-closed interviews and documentation. Informants who agreed to be interviewed until the study discussions ended were 9 manager. More detailed interviews conducted by researchers at the respondent who was able to explain the substance of this research study. Our questionnaire consisted of three sections, which included the SCF, competitiveness and multiple firm performance questions. A five-point Likert scale was employed with a score of 1, indicating "strongly disagree", and 5, representing "strongly agree", to extract the different attitudes of respondents (Malhotra, 2010; Cooper \& Sehindler, 2003). The questionnaire was pre-tested by three professionals 
with extensive experience in SCM practices. According to their recommendations from the pre-test result, several questions were consequently rewritten.

\section{Data Analysis and Results}

Data was analyzed using Generalized Structured Component Analysis (GSCA). GSCA is a component-based SEM method which can be used for calculating scores and allows for very small samples (Heungsun Hwang et al., 2010). This method is chosen for the following consideration: (1) the model in a conceptual framework consists of hierarchical causal relations, that is SCF influencing competitiveness and then influencing performance, and one mediating role of competitiveness towards performance; (2) GSCA is suitable for confirming the unidimensionality of various latent variable indicators, both reflexive and formative; (3) GSCA is a powerful method of analysis that does not require many assumptions and can be performed on a series of latent variables simultaneously, hence an efficient statistical tool; (4) methods GSCA it easy to operate, does not require any modifications to the index and accurate to generalize from a relatively small sample.

Evaluation on the is GSCA model in this research was initiated by a measure of fit on the measurement model. This aims to examine or test whether the research instrument is valid or reliable in explaining or reflecting the latent variables. Table 1 shows the mean, estimate loading, AVE and alpha of each indicator variable. The measurement model for all latent variables in Table 1 shows that the estimated value at loading for all indicators have values which are larger than .70 (Solimun 2010; Heungsun Hwang et al., 2010) and the value of CR is significant at the confidence of $95 \%(\alpha=.05)$. This reflects that the correlation of all indicator variables are positive and significant and valid for being used in reflecting the measurement of the latent variable, that is SCF, performance and competitiveness of the company. The critical value $\left(\mathrm{CR}^{*}\right)$ shows that all indicators can be used in measuring latent variables since the values of $\mathrm{CR}^{*}$ are significant at $\alpha=.05$. 
Table 1. Mean, Estimated Loading, AVE and Alpha

\begin{tabular}{lllllll}
\hline Constructs & Indicators & Mean & Loading & & \multirow{2}{*}{ AVE } & Alpha \\
\cline { 3 - 4 } & & & Estimate & CR & & \\
\hline \multirow{2}{*}{ SCF } & Supply flexibility & 3.65 & .913 & $29.39^{*}$ & .733 & .877 \\
& Production flexibility & 3.83 & .819 & $14.65^{*}$ & & \\
& Delivery flexibility & 3.75 & .871 & $24.0^{*}$ & & \\
& Product development flexibility & 3.45 & .818 & $14.76^{*}$ & & \\
Competitiveness & Pricing & 3.90 & .847 & $13.67^{*}$ & .670 & .901 \\
& Production quality & 3.95 & .849 & $16.09^{*}$ & & \\
& Delivery dependability & 3.26 & .874 & $19.38^{*}$ & & \\
& Product innovation & 3.36 & .807 & $14.93^{*}$ & & \\
& Time to market & 3.76 & .765 & $15.4^{*}$ & & \\
& Post-sales services to suppliers & 3.57 & .761 & $9.34^{*}$ & & \\
Firm Performance & Cost reduction & 3.78 & .890 & $27.04^{*}$ & .785 & .862 \\
& Lead-time reduction & 3.70 & .863 & $19.72^{*}$ & & \\
& Stock-out reduction & 3.73 & .905 & $17.23^{*}$ & & \\
\hline
\end{tabular}

Note: $\mathrm{CR}^{*}=$ significant at $\alpha=.05, \mathrm{AVE}>.05$ and Alpha $>.70$

The value of AVE (Average Variance Extracted) for all latent variables is greater than .50 (Hwang et al., 2010), and therefore the latent variables have adequate discriminant validity. Therefore, the research instrument for measuring all latent variables has fulfilled the criteria for discriminant validity. Next, the alpha for all constructs is greater than .70, meaning that all latent variables have adequate composite reliability. It can be concluded that the research instrument in the measurement have fulfilled the criteria since it has a high level of fit and reliability.

Structural model evaluation was performed after the model relationship was built in accordance with the data observation and goodness-of-fit models overall. This is evident from the values of FIT, AFIT, GFI (unweighted least squares) and SRMR (standardized root mean square residual). The result of the test for relation among variables is evident from the values of path coefficient and critical point $\left(\mathrm{CR}^{*}\right)$, which is significant at $\alpha=.05$, as shown in Figure 2. The goodness of fit of the structural model and overall model shows that the model specified in this research can explain $67.30 \%$ of the variance of the corrected data (adjusted FIT). Also, the value of GFI $=.995$ and SRMR $=.102$ shows that the model has sufficient fit since recommended GFI is $\geq .90$ and SRMR is considered to be better when it is closer to zero (Solimun 2010; Heungsun Hwang et al., 2010; Jorg Henseler, 2012).

Figure 2 and Table 2 show that direct effect of SCF on competitiveness can be proved. Coefficients value estimation the effect SCF on competitiveness was 0.912 with a probability value of $0.000(\mathrm{p}<0.05)$. The test results prove the better SCF implementation, the higher firm competitiveness. The higher SCF , the higher competitiveness. Therefore, the hypothesis (H1) can be accepted or supported by empirical evidence. The results of interviews with 
"Operational Manager A" was also supported, suggesting that SCF both in firms and business partners, particularly with suppliers in meeting fish supply need, can improve firm ability to serve the growing demand and diverse consumer tastes. In addition, competitiveness can be achieved, according to target of management firm. Therefore, the SCF effectively make benefits due increased competitiveness of fisheries.

Path coefficients the effect of SCF on firm performance was 0.096 , with a probability value of $0.384(p>0.05)$. Test results are not able to prove empirically. Therefore, the hypothesis (H2), which stated that SCF significantly influence firm performance, rejected. If you look at respondents characteristics by job title, implementation of SCF in Southeast Sulawesi fishery firms still become full responsibility at management level. In fact, SCF should be the responsibility of all levels. The results of interviews with "SCM manager B" indicates the responsibility of SCF only at management level. Operational level, which was responsible for the firm daily operations, still less understand the meaning and function of SCF . Therefore, the fishery firm in Southeast Sulawesi should communicate at all levels in firm about the function and implementation of SCF.

Direct influence of competitiveness on firm performance generate an estimated path coefficient of 0.456 , with a probability value of $0.011(\mathrm{p}<0.05)$. The test results indicate that there was enough empirical evidence to accept the hypothesis (H3), which stated that competitiveness has significant effect on firm performance. Thus, the higher competitiveness, the higher firm performance. Today, the Indonesian fisheries sector strive for competitiveness, although ability of the fishing industry was still low. As noted by the "SCM Manager C" quality guarantee and value added products was a key to winning the competition in global trade era. Ministry was prioritizes higher competitiveness and value added through improved supply chain and value chain management, using the following four strategies: (1) increase fisheries production through various programs, namely: provision of larger vessel to replace small vessels were now used by fishermen, (2) increasing aquaculture production, (3) increasing the production of high value-added processed products, by increasing the SMEs capacity and processing industrialization, (4) developing supporting industries and other related industries.

Mediating variables of competitiveness in Table 2 and Figure 2 show that SCF affect on competitiveness and competitiveness affect on firm performance. Furthermore, SCF directly has no significant effect on firm performance. Therefore, competitiveness variables in research model was said as complete mediation. There was enough empirical evidence to accept (H4), the high competitiveness act as mediating the relationship between SCF and performance. That was, the SCF directly has no significant effect on firm performance. However, through competitiveness as mediation variable, SCF significantly can affect firm performance. 


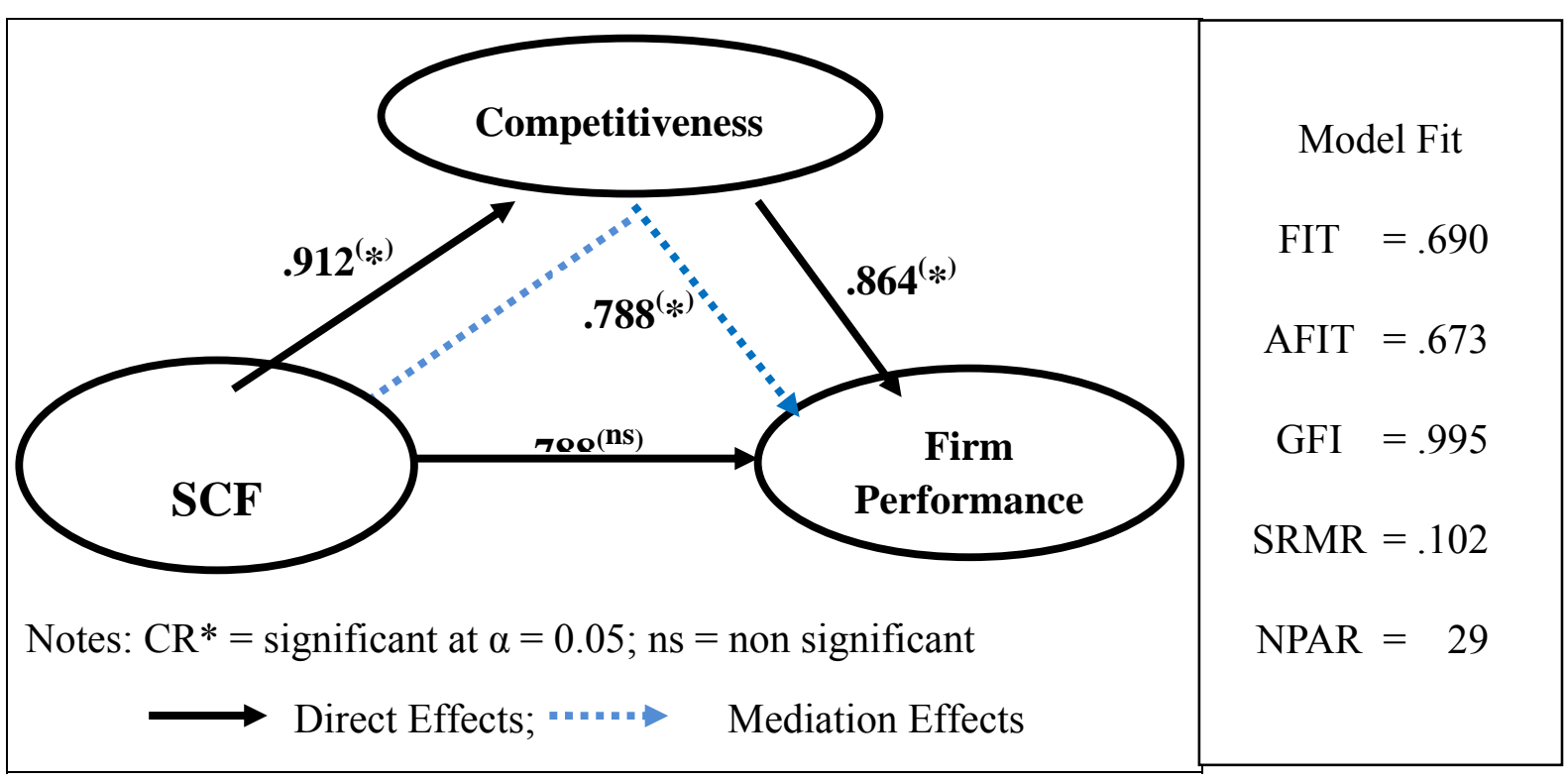

Figure 2. Diagram for Hypothesis Testing and Path Coefficient for GSCA

Table 2. Hypothesis Testing and Path Coefficient for GSCA

\begin{tabular}{|c|c|c|c|c|}
\hline Direct Influence & $\begin{array}{l}\text { Path } \\
\text { Coefficients }\end{array}$ & $\mathrm{CR}$ & $\mathrm{P}$-value & Empirical Evidence \\
\hline H1. SCF --> Competitiveness & .912 & $31.02^{*}$ & .000 & Significant Accepted \\
\hline H2. SCF --> Firm Performance & .096 & .88 & .384 & $\begin{array}{l}\text { Non Rejected } \\
\text { Significant }\end{array}$ \\
\hline $\begin{array}{l}\text { H3. Competitiveness } \quad--> \\
\text { Performance }\end{array}$ & $\begin{array}{ll}\text { Firm } & .864\end{array}$ & $8.04^{*}$ & .000 & Significant Accepted \\
\hline
\end{tabular}

Test For The Impact Of Mediating Variable

\begin{tabular}{llllll}
\hline Exogenous & Mediation & Endogenous & $\begin{array}{l}\text { Path } \\
\text { Coefficient }\end{array}$ & $\begin{array}{l}\text { Nature } \\
\text { Mediation }\end{array}$ & of Empirical Evidence \\
\hline \multirow{2}{*}{ H4.SCF } & & & Competitiveness & --> & Firm \\
& & Performance & & Complete & Significant Accepted \\
& & & Mediation & \\
\hline
\end{tabular}

$\mathrm{CR}^{*}=$ significant at .05 level

\section{Discussion}

SCF was ability of supply chain partners (suppliers and customers) to respond the changes in achieving or maintaining market competitiveness. Responsiveness of supply chain partners must be integrated, particularly through flexibility in supply; products development; production, and delivery. Fishery SCF in Southeast Sulawesi was able to contribute on competitiveness. Test results demonstrate the SCF has significant and positive effect on competitiveness. That is, the empirical evidence prove that better implementation of SCF has 
increased firm competitiveness. Variable measurement model of SCF was more dominant, reflected by supply flexibility indicator. These results confirm ability of the supplier (fish collector) to provide a fresh supply with needed quantity, delivering fish supply timely and quality suitable with firm demand, to determine the increase of delivery dependability, a reflection of competitiveness. If related to studied products characteristics, fish need of a fast process (speed of delivery), because it was very important and determine the product quality of fishery firms.

Research findings reinforce the theory of SCF. This is consistent with the theory of SCF proposed by Pujawan (2005), which states that the concept of SCF should be considered as primary determinant in competitiveness. Gary Hamel et al., (1998) states that SCF is the ability of partners in a supply chain to respond to the changes in the market and to maintain competitiveness. The findings of this research is also consistent with resource-based view, which is one of the complementary theories in SCM (Arni Halldorsson et al., 2007), which states that a company can improve its competitiveness by developing and using a set of unique, valuable, rare, inimitable and irreplaceable resources.

The findings of this study supports (Kamel A. Fantazy et al., 2007 \& Pujawan, 2004) that SCF has significant impact on competitiveness. The company should know how far SCF should be implemented in order to achieve competitiveness, which is understood in terms of cost, quality, innovation and time to market (Vinod Kumar et al., 2006). Angel \& Manuela (2005) states that SCF can improve company competitiveness, especially for the implementation of decision making processes and technology implementation, which is important in the improvement of competitiveness. Mark Stevenson \& Martin Spring (2007) states that improving competitiveness in the global era would require a kind of SCF which is not only capable of paying attention to environmental uncertainties but also other factors, such as cooperation, collaboration, and coordination, in internal and external.

The result of analysis shows that SCF does not have significant impact on performance. The implementation of SCF as measured through supply flexibility, production flexibility, delivery flexibility, and products development flexibility, has not contributed to company performance. This indicates that supply flexibility has the dominant role in reflecting SCF but it has not been performed well. One of the causes for lack of impact from SCF to performance is the need to attend to uncertainties within the supply chain. Supplier uncertainty (fish suppliers) is one of the primary causes for the bullwhip effect (where fluctuation of demand cannot be anticipated by the firm). The companies certainly have tried to manage this effect as much as possible, but seasonal factor results in a highly fluctuating fish supply and this has caused large amount of loss for the companies. The loss sustained by the companies has resulted in lower performance. These conditions will lead to what was called as nervousness. Nervousness create lost opportunity, firm inability to meet existing demand. Gradually, this situation could lead fishery firms can not able to compete in market.

These results reinforce the findings of Kamel A. Fantazy et al. (2009) that SCF does not have significant impact on company performance. The result of this research has also confirmed the propositions of theoretical studies (Duclos et al., 2003; Vinod Kumar et al., 2006), which 
states that anticipating uncertainties in a supply chain is the primary concern for determining SCF. This is different from the findings of Angel \& Manuela (2005) that SCF has significant impact in improving company performance. Mark Stevenson \& Martin Spring (2007) has provided a wider perspective on the meaning of SCF and has explained that flexibility is closely related to uncertainty. Therefore, they also criticize existing studies on SCF for their lack of attention to the inter-organizational indicators.

Competitive advantage has positive and significant effect on firm performance. That is, the higher competitiveness, the higher firm performance. Thus, competitiveness variables can explain the variation changes in fishery firm performance. Competitive advantage in fishery firms today is not only determined by ability to create more output per unit of time. Productivity was important, but not enough to compete in the market. Customers can differentiate products based on quality. It must be realized that quality of the product depends on process, people and delivery dependability. The fishery firm managers should be aware that delivery dependability, an advantage in products delivery to customers compared to competitors, was a reflection of competitiveness that can support firm performance improvement. Therefore, competitiveness can explain the variance in fishery firm performance. This lends support to Krajewski et al. (2010) that high competitiveness can support improvement of company performance.

This finding is also consistent with theories on competitiveness (Porter, 2008; David et al., 2011) that competition is the core of company success and failures and that competition determines the appropriateness of company activities which can support company performance. This research findings is consistent with previous studies (Suhong Li et al., 2006; Gimenez \& Ventura, 2005; Soo W. Kim, 2006a; Rajesh \& Margaret, 2009; Glenn Richey et al., 2009), which found that high competitiveness can improve performance directly. Our research was carried out with large-scale fishery companies and therefore the result of our study supports Soo W. Kim (2006b) which states that competitiveness has significant impact on performance for large-scale firm. Our finding is different from (Ting Chi et al., 2009) that there is no significant relation between priorities of competition and performance of supply chain in companies with low performance.

Analysis of SCF, that mediated by competitiveness, influences the path of firm performance, generating positive and significant coefficient. This result means that there was empirical evidence that high competitiveness role was able to mediate the relationship between SCF on firm performance improvement. The nature of mediation suggests the competitiveness was complete mediation. That is, competitiveness significantly influenced by SCF and competitiveness significantly affect firm performance. However, SCF directly has no significant effect on firm performance. Good implementation of SCF would not directly improve performance but can only do so through the mediation of competitiveness, which has significant impact on performance. This finding supports the theory of SCF from (Pujawan, 2004; Candace et al., 2011), which states that SCF should be considered a primary determinant in the improvement of performance through the support of high level of competitiveness. This result confirms the proposition of (Mark Stevenson \& Martin Spring, 2007; Kamel A. Fantazy et al., 2009) which state that flexibility of supply chain cannot have 
significant impact on performance, but the concept of SCF should be expanded by including competitiveness.

\section{Theoretical and Managerial Implications}

The result of this research is expected to provide insight on the concept of SCF, which began from the concept of manufacturing flexibility as developed by (Gary Hamel et al., 1998; Duclos et al., 2003; Pujawan, 2005) and also to give insights to the theoretical propositions (Candace et al., 2011; Quah Hock \& Zulkifli, 2011), which state that SCF should be approached in an integrated manner by observing the ability of supply chain partners in order to respond to market changes which can be considered as determinants for the competitiveness and performance. Critiques on the concept of SCF state that SCF is still overly focused on how environmental uncertainty can influence SCF, while actually there are factors playing important role here, that is inter-organizational relation, which has important role in the implementation of SCF so that competitiveness and performance can be improved. This lends support to the propositions in literature reviews (Mark Stevenson \& Martin Spring, 2007; Candace et al., 2011).

The theoretical contribution of this research is expected to be able to develop the science of operational management, especially SCM in the effort to implement SCF, competitiveness, and performance. The contribution of this research is also expected to be able to develop a conceptual and theoretical understanding on SCF in the effort to improve company competitiveness and performance, especially for fishery companies. The result of this research brings additional evidence on SCF, which are now lacking in attention in research since so far the concept of SCF is related only to environmental uncertainty.

The practical contribution of this research is the managerial implication of the need to manage SCF in order to improve competitiveness and performance for fishery companies. The result of this research provides knowledge and insight for the managers concerning the need to implement SCF in an integrated manner and not only by observing the ability of the supply chain partners in responding to market changes in achieving and maintaining competitiveness and performance. The last is that directors and managers of fishery companies as leaders in the future should drive the implementation of SCF.

\section{Conclusion, Limitations and Future Research}

This study intends to contribute to existing literature on SCM by investigating the impact of SCF on firm performance and the mediating role of competitive advantage. The results showed the implementation of good SCF can improve competitiveness and performance of fishery firm. Implementation of supply, production, delivery, and product development flexibility have an important role in supporting the achievement of SCF implementation. It can make a real contribution to improving competitiveness and performance of fishery firm. Implementation of SCF dominantly was reflected by supply flexibility, while competitiveness dominantly was reflected by delivery dependability. That is, supply flexibility, as measured by suppliers ability to provide the quantity fish needed, fish supplies delivered on time and quality suitable with firm demand, will improve delivery dependability. Delivery 
dependability was an advantage in product delivery, as a reflection of competitiveness. This result was supported also by fishery products with perishable characteristics. Therefore, the fast handling (speed of delivery) was required to improve the quality of fishery firm products.

Improved performance cannot be separated from application good fishery SCF. The results of this study indicate that effect of chain flexibility on firm performance has not made a significant contribution. This result was due to the uncertainty of fish supplier, the main causes of the bullwhip effect (fluctuations in demand that cannot be anticipated by firm). Firm definitely trying to push as low as the bullwhip effect factors. However, seasonal factors cause the supply of fish was very fluctuating, causing huge losses for firm. Losses impact on firm performance. In addition, the condition can lead to nervousness. Nervousness create a lost opportunity where firm unable to meet existing demand. Gradually, this condition can lead fishery firms unable to compete in market.

High competitiveness can improve firm performance. These results indicate that better firm delivery dependability, compared to competitors, was the dominant factor in supporting firm competitiveness. This contributed significantly to the improved fishery firm performance. Furthermore, the results of this research could prove a real role of competitiveness, as mediating the relationship between SCF to improve performance of fishery firms in the Southeast Sulawesi. This means that good implementation of SCF, directly does not able to significantly improve firm performance. But through the mediating role of competitiveness, SCF can significantly affect firm performance.

Based on these results, given the wide scope of the discussion and the large variation in firm environment change, this study has limitations in presenting the relationship of a cross-sectional analysis. Changing business environment need to be identified. Therefore, further research with longitudinal design was needed to re-examine whether the relationship between the variables analyzed in the study had changed. Furthermore, The accuracy for the model of this study is .673. This means that $67.30 \%$ of the variance in the variable of SCF, competitiveness and performance can be explained by the model and the remaining $32.70 \%$ is explained by other variables. Therefore, further studies in the future can develop a research model by adding other variables such as: characteristics of supply chain environment, structure of supply chain, integrated information (IT), and culture of quality. The regional government should be more proactive in dealing with the existence of fishery companies in Southeast Sulawesi as one of the components of the supply chain in making use of existing facilities to regulate private fishermen, unloading and auction of fish. Improvement and procurement of infrastructure is necessary for improving competitiveness and firm performance.

\section{References}

Angel Martı'nez Sa'nchez, \& Manuela Pe'rez. (2005). Supply chain flexibility and firm performance A conceptual model and empirical study in the automotive industry. International Journal of Operations \& Production Management, 25(7), 681-700. http://dx.doi.org/10.1108/014435705106050900 
Arni Halldorsson; Herbert Kotzab, Juliana H. Mikkola, \& Tage Skjøtt-Larsen. (2007). Complementary theories to supply chain management. Supply Chain Management: An International Journal, 12(4). 284-296. http://dx.doi.org/10.1108/13598540710759808

Candace Y. Yi, E.W.T. Ngai, \& K-L. Moon. (2011). supply chain flexibility in an uncertain environment: Exploratory findings from five case studies. Supply Chain Management: An International Journal, 16(4), 271-283. http://dx.doi.org/10.1108/13598541111139080

(Central Statistics Agency [CSA]. (2011). Southeast Sulawesi in Figures 2011. Published Statistic Sultra Province. Kendari.

Creswell J. W. (2011). Research Design Qualitative, Quantitative, and Mixed Methods Approaches. ( $3^{\text {th }}$ ed.). Sage, Los Angles.

Cooper, D. R., \& Schindler, P. S. (2003) Business Research Methods ( $8^{\text {th }}$ ed.). McGraw-Hill, New York.

David Peng; Roger G. Schroeder, \& Rachna Shah. (2011). Competitive priorities, plant improvement and innovation capabilities, and operational performance A test of two forms of fit. International Journal of Operations \& Production Management, 31(5), 484-510. http://dx.doi.org/10.1108/01443571111126292

Duclos Leslie K., Robert J. Vokurka, \& Rhonda R. Lummus. (2003). A Conceptual Model of Supply Chain Flexisibility. Industrial Management \& Data systems, 103(6), 446-45. http://dx.doi.org/10.1108/02635570310480015

Gary Hamel; C.K. Prahalad; Howard Thomas, \& Don O’Neal. (1998). Strategic Flexibility Managing in a Turbulent Environment, John Wiley \& Sons.

Ghozali Imam. (2008). Generalized Structured Component Analysis (GSCA). Badan Penerbit Universitas Dipanegoro. Semarang

Gimenez, C., \& Ventura, E. (2005). Logistic-Production, Logistic-Marketing and External Integration Their Impact on Performance, International Journal of Operations and Production Management, 25(1), 20-38. http://dx.doi.org/10.1108/01443570510572222

Gimenez, C., \& Ventura, E. (2003) Supply chain management as a competitive advantage in the Spanish grocery sector. International Journal of Logistics Management, 14(1), 77-88. http://dx.doi.org/10.1108/09574090310806558

Glenn Richey Jr, Haozhe Chen, Rahul Upreti, \& Frank G. Adams. (2009). The moderating role of barriers on the relationship between drivers to supply chain integration and firm performance. International Journal of Physical Distribution \& Logistics Management, 39(10), 826-840. http://dx.doi.org/10.1108/09600030911011432

Heizer. J., \& Render B. (2010) Operations Management (Manajemen Operasi), Edisi 9 Penerbit Salemba Empat. Jakarta

Heungsun Hwang, Naresh K. Malhotra, Youngchan Kim, Marc A. Tomiuk, \& Sungjin Hong. (2010). A Comparative Study on Parameter Recovery of Three Approaches to Structural 
Equation Modeling. Journal of Marketing Research, 47(4), 699-712. http://dx.doi.org/10.1509/jmkr.47.4.699

Jorg Henseler. (2012) Why generalized structured component analysis is not universally preferable to structural equation modeling. Journal of the Academy of Marketing Science. 40(3), 402-413, http://dx.doi.org/10.1007/s11747-011-0298-6

Kamel Aissa Fantazy, Vinod Kumar, \& Uma Kumar. (2009). An empirical study of the relationships among strategy, flexibility, and performance in the supply chain context. Supply Chain Management: An International Journal, 14(3), 177-188. http://dx.doi.org/10.1108/13598540910954520

Krawjeski L. J., Rizmant L. P, \& Malhotra M. K. (2010). Operation Managemen, Processes and Supply Chains. $\left(9^{\text {th }}\right.$ ed.). Pearson Education, New York.

Malhorta Naresh K. (2010). Marketing Research, An Applid Orientantion. (6 ${ }^{\text {th }}$ ed.) Pearson Education.

Mark Stevenson, \& Martin Spring. (2007). Flexibility from a supply chain perspective: definition and review. International Journal of Operations \& Production Management, 27(7), 685-713. http://dx.doi.org/10.1108/01443570710756956

Porter, M. C. (2008). Competitive Advantage (Keunggulan Bersaing) Menciptakan dan Mempertahankan Kinerja Unggul. Terjemahan, Publishing Group Karisma. Jakarta.

Pujawan. (2004). Assessing SCF: A Conceptual Famework \& Case Study. Int. J. Integrated Supply Management, 1(1), 79-97. http://dx.doi.org/10.1504/IJISM.2004.004599

Pujawan. (2005). Supply Chain Management. Edisi Pertama. Guna Widya. Surabaya.

Quah Hock Soon, \& Zulkifli Mohamed Udin. (2011). Supply chain management from the perspective of value chain flexibility: an exploratory study. Manufacturing Technology Management, 22(4), 506-526. http://dx.doi.org/10.1108/17410381111126427

Rajesh Rajaguru, \& Margaret Jekanyika Matanda. (2009) Influence of inter-organisational integration on business performance The mediating role of organizational-level supply chain functions. Journal of Enterprise Information Management, 22(4), 456-467. http://dx.doi.org/10.1108/17410390910975059

Soeryanto Eddy. (2010). Manajemen Kinerja Falsafah, Konsep \& Aplikasinya, Universitas Komputer Indonesia. Jakarta

Solimun. (2012). Pemodelan Generalized Structured Component Analysis (GeSCA). Program Studi Statistika FMIPA, PDIM FE Universitas Brawijaya. Malang.

Soo Wook Kim. (2006a). Effects of Supply chain management practices, integration and competition capability on performance. Supply Chain Management: An International Journal, 11(3), 241-248. http://dx.doi.org/10.1108/13598540610662149 


\section{Macrothink}

Journal of Management Research

ISSN 1941-899X

2013, Vol. 5, No. 1

Soo Wook Kim. (2006b). The effect of supply chain integration on the alignment between corporate competitive capability and supply chain operational capability. International Journal of Operations \& Production Management, 26(10), 1084-1107. http://dx.doi.org/10.1108/01443570610691085

Suhong Li, Bhanu Ragu-Nathan, T.S. Ragu-Nathan, \& Subba Rao. (2006). The impact of supply chain management practices on competitive advantage and organizational performance. Omega, 34(1), 107-124. http://dx.doi.org/10.1016/j.omega.2004.08.002

Ting Chi, Peter P.D. Kilduff, \& Vidyaranya B. Gargeya, (2009). Alignment Between Business Environment Characteristics, Competitive Priorities, Supply Chain Structures, and Firm Usiness Performance. International Journal of Productivity and Performance Management, 58(7), 645-669. http://dx.doi.org/10.1108/17410400910989467

Vinod Kumar, Kamel A. Fantazy, Uma Kumar, \&Todd A. Boyle. (2006). Implementation and management framework for supply chain flexibility. Journal of Enterprise Information Management, 19(3), 303-319. http://dx.doi.org/10.1108/17410390610658487

\section{Appendix 1. Data Processing Result GSCA}

\begin{tabular}{|c|c|}
\hline \multicolumn{2}{|c|}{ Model Fit } \\
\hline FIT & 0.690 \\
\hline AFIT & 0.673 \\
\hline GFI & 0.995 \\
\hline SRMR & 0.102 \\
\hline NPAR & 29 \\
\hline
\end{tabular}


Measurement Model

\begin{tabular}{|c|c|c|c|c|c|c|c|c|c|}
\hline \multirow[t]{2}{*}{ Variable } & \multicolumn{3}{|c|}{ Loading } & \multicolumn{3}{|c|}{ Weight } & \multicolumn{3}{|c|}{ SMC } \\
\hline & Estimate & SE & $\mathrm{CR}$ & Estimate & SE & $\mathrm{CR}$ & Estimate & SE & $\mathrm{CR}$ \\
\hline $\operatorname{SCF}(X)$ & \multicolumn{9}{|c|}{$\mathrm{AVE}=0.733$, Alpha $=0.877$} \\
\hline $\mathrm{X} 1$ & 0.913 & 0.031 & $29.39^{*}$ & 0.337 & 0.035 & $9.6^{*}$ & 0.833 & 0.055 & $15.15^{*}$ \\
\hline $\mathrm{X} 2$ & 0.819 & 0.056 & $14.65^{*}$ & 0.311 & 0.019 & $15.94^{*}$ & 0.672 & 0.088 & $7.62^{*}$ \\
\hline $\mathrm{X} 3$ & 0.871 & 0.036 & $24.0^{*}$ & 0.257 & 0.027 & $9.52^{*}$ & 0.759 & 0.062 & $12.24^{*}$ \\
\hline $\mathrm{X} 4$ & 0.818 & 0.055 & $14.76^{*}$ & 0.261 & 0.034 & $7.64^{*}$ & 0.669 & 0.086 & $7.75^{*}$ \\
\hline Competitiveness (Y1) & \multicolumn{9}{|c|}{$\mathrm{AVE}=0.670$, Alpha $=0.901$} \\
\hline Y11 & 0.847 & 0.062 & $13.67^{*}$ & 0.230 & 0.041 & $5.59^{*}$ & 0.718 & 0.101 & $7.1^{*}$ \\
\hline $\mathrm{Y} 12$ & 0.849 & 0.053 & $16.09^{*}$ & 0.157 & 0.038 & $4.11^{*}$ & 0.721 & 0.085 & $8.53^{*}$ \\
\hline Y13 & 0.874 & 0.045 & $19.38^{*}$ & 0.175 & 0.032 & $5.47^{*}$ & 0.764 & 0.077 & $9.98^{*}$ \\
\hline $\mathrm{Y} 14$ & 0.807 & 0.054 & $14.93^{*}$ & 0.206 & 0.038 & $5.34^{*}$ & 0.652 & 0.084 & $7.78^{*}$ \\
\hline Y15 & 0.765 & 0.050 & $15.4^{*}$ & 0.234 & 0.031 & $7.44^{*}$ & 0.585 & 0.075 & $7.84^{*}$ \\
\hline Y16 & 0.761 & 0.082 & $9.34^{*}$ & 0.228 & 0.027 & $8.31^{*}$ & 0.580 & 0.119 & $4.89^{*}$ \\
\hline $\begin{array}{l}\text { Firm Performance } \\
\text { (Y2) }\end{array}$ & \multicolumn{9}{|c|}{ AVE $=0.785$, Alpha $=0.862$} \\
\hline Y21 & 0.890 & 0.033 & $27.04^{*}$ & 0.388 & 0.034 & $11.42^{*}$ & 0.792 & 0.057 & $13.96^{*}$ \\
\hline Y22 & 0.863 & 0.044 & $19.72^{*}$ & 0.334 & 0.024 & $13.72^{*}$ & 0.744 & 0.075 & $9.92^{*}$ \\
\hline $\mathrm{Y} 23$ & 0.905 & 0.053 & $17.23^{*}$ & 0.406 & 0.028 & $14.5^{*}$ & 0.820 & 0.091 & $9.0^{*}$ \\
\hline
\end{tabular}

$\mathrm{CR}^{*}=$ significant at .05 level 
Structural Model

\begin{tabular}{|c|c|c|c|c|}
\hline \multicolumn{5}{|c|}{ Path Coefficients } \\
\hline & Estimate & $\mathrm{SE}$ & $\mathrm{CR}$ & P-value \\
\hline SCF (X)--> Competitiveness (Y1) & 0.912 & 0.029 & $31.02^{*}$ & 0.000 \\
\hline SCF (X)--> Firm Performance (Y2) & 0.096 & 0.110 & 0.88 & 0.384 \\
\hline Competitiveness (Y1) --> Firm Performance (Y2) & 0.864 & 0.107 & $8.04^{*}$ & 0.000 \\
\hline
\end{tabular}

$\mathrm{CR}^{*}=$ significant at .05 level

\begin{tabular}{|l|c|c|}
\hline \multicolumn{1}{|c|}{ Variable } & R square of Latent Variable & Means Scores of Latent Variables \\
\hline SCF $(\mathrm{X})$ & 0 & 3.677 \\
\hline Competitiveness (Y1) & 0.832 & 3.638 \\
\hline Firm Performance (Y2) & 0.907 & 3.739 \\
\hline
\end{tabular}

\begin{tabular}{|l|c|c|c|}
\hline \multicolumn{4}{|c|}{ Correlations of Latent Variables (SE) } \\
\hline \multicolumn{1}{|c|}{ Variable } & $\begin{array}{c}\text { Supply chain } \\
\text { flexibility (X) }\end{array}$ & Competitiveness (Y1) & Firm Performance (Y2) \\
\hline SCF (X) & 1 & $0.912(0.029)^{*}$ & $0.884(0.041)^{*}$ \\
\hline Competitiveness (Y1) & $0.912(0.029)^{*}$ & 1 & $0.952(0.021)^{*}$ \\
\hline Firm Performance (Y2) & $0.884(0.041)^{*}$ & $0.952(0.021)^{*}$ & 1 \\
\hline
\end{tabular}

$*$ significant at .05 level 